\section{Acute hepatitis due to infectious mononucleosis in a 21-year-old-man}

\author{
VITORINO MODESTO DOS SANTOS ${ }^{1,2}$, ZILCEM DA COSTA ARRUDA JR ${ }^{1}$, \\ MAIRA DE FARIAS POLCHEIRA ${ }^{1}$, DIOGO WAGNER DA SILVA DE SOUZA ${ }^{1}$, \\ ALESSANDRA MARIA RODRIGUES OLIVEIRA SANTOS ${ }^{1}$, \\ MARCELA SANTOS CORRÊA DA COSTA ${ }^{2}$
}

\begin{abstract}
A 21-year-old male was admitted because of fever, fatigue, headache, pharyngitis, abdominal pain, loss of appetite, vomiting and dark urine for three days. The patient denied recent use of medicines or any other drug. His physical examination disclosed jaundice, hepato-splenomegaly, whitish-yellow covered tonsils, bilateral anterior and posterior cervical lymph node enlargement associated with edema on the face and neck. Routine blood tests detected abnormalities in serum bilirubins and liver enzymes (total bilirubin: $14.5 \mathrm{mg} / \mathrm{dl}$, direct-reacting bilirubin: $12.9 \mathrm{mg} / \mathrm{dl}$, AST: 697 U/l, ALT: 619 U/l, alkaline phosphatases: 260 U/l, and GGT: 413 U/l). Serological tests showed negative results for viral hepatitis, cytomegalovirus, HIV-1 and HIV-2, and toxoplasmosis markers, while serology for recent infection by $E B V$ was positive (IgM: 70 and $29 \mathrm{U} / \mathrm{ml}$; EBV IgG: 25 and $156 \mathrm{U} / \mathrm{ml}$ ). Although infrequently, EBV infection can cause acute hepatitis with accentuated cholestatic jaundice (5\% of cases), which may constitute an additional diagnostic challenge for primary care physicians. The patient improved with supportive management and was discharged after 12 days. This case study might contribute to increase the suspicion index about acute hepatitis related to EBV.
\end{abstract}

(Rev Med Chile 2013; 141: 917-921).

Key words: Epstein-Barr virus; Hepatitis, viral, human; Infectious mononucleosis; Young adults.

\section{Hepatitis aguda por mononucleosis infecciosa en un varón de 21 años}

Un paciente varón de 21 años, fue hospitalizado por fiebre, astenia, cefalea, faringitis, dolor abdominal, pérdida del apetito, vómitos y orina oscura desde tres días antes. El paciente negó uso reciente de medicamentos y cualquier otra droga. Su examen físico reveló ictericia, hepato-esplenomegalia, amigdalitis, adenopatías cervicales anteriores y posteriores, asociadas con edema facial y cervical. Los exámenes de laboratorio mostraron elevación sérica de bilirrubina y enzimas hepáticas (bilirrubina total: 14,5 mg/dl, bilirrubina directa: 12,9 mg/dl, AST: $697 \mathrm{U} / \mathrm{l}$, ALT: 619 U/l, fosfatasas alcalinas: $260 \mathrm{U} / \mathrm{l}$, y gama-GT: $413 \mathrm{U} / \mathrm{l})$. Los tests serológicos resultaron negativos para hepatitis viral A, Bo C, citomegalovirus, VIH-1 y VIH-2, y toxoplasmosis; pero la serología de infección reciente por VEB fue positiva (IgM: 70 y $29 \mathrm{U} / \mathrm{ml}$; IgG: 25 y $156 \mathrm{U} / \mathrm{ml}$ ). Aunque raramente, las infecciones por VEB pueden causar una hepatitis aguda con acentuada ictericia colestásica (5\% de los casos), que suele constituir un desafío diagnóstico adicional para los médicos en atención primaria. El paciente mejoró durante un tratamiento de apoyo y recibió alta hospitalaria después de 12 días. Este caso estimula a aumentar el indice de sospecha de hepatitis aguda relacionada con $\mathrm{VEB}$.

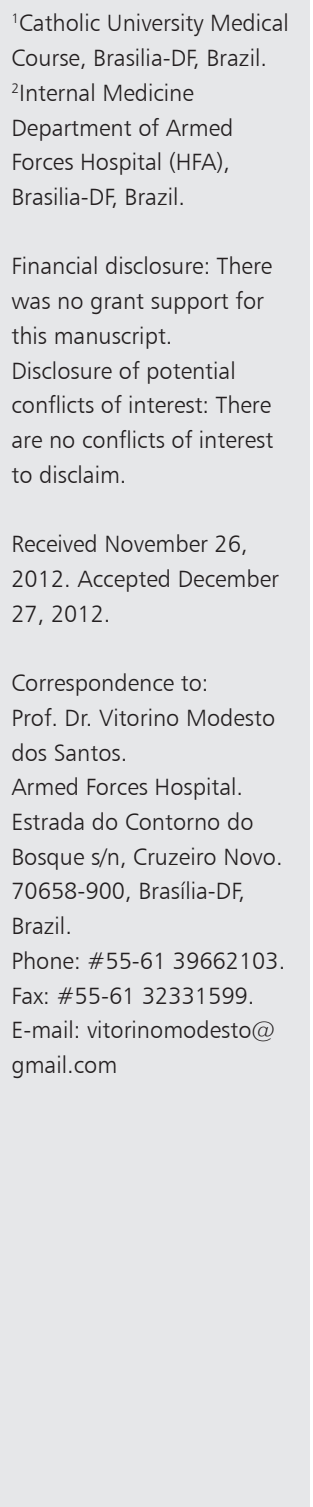


$\mathrm{E}$ pstein-Barr virus (EBV) is a member of the Herpesviridae family and the causal agent of infectious mononucleosis (IM) ${ }^{1}$, which is also called Pfeiffer's disease, kissing disease, glandular fever, and monocytic angina. In Brazil as well as in Chile, IM more often occurs among children, adolescents, and young adults ${ }^{2}$, with high seroprevalence of EBV in adults ${ }^{3}$. The acute manifestations of primary IM are usually benign, but its severity and the duration of the disease are variable. Chronic active infection and diverse malignancies have been associated with EBV, including gastric and nasopharyngeal carcinomas, Burkitt's and Hodgkin's lymphomas, and leukemia ${ }^{1,4,5}$. Classical features of IM are fever, pharingo-tonsilitis, lymph node enlargement, hepato-splenomegaly, and lymphocytosis with large number of atypical lymphocytes ${ }^{6-9}$. The wide spectrum of signs and symptoms of IM may pose diagnostic challenges, with under recognition or misdiagnosis. Severe or fatal IM is very rare, but is growing in number, and may involve hemophagocytic lymphohistiocytosis and fulminant hepatitis ${ }^{4,5}$. The management of IM is based on supportive care, including adequate rest and well controlled hydration and nutrition, with the exception of some severe complications ${ }^{8,10}$. IM can cause mild to moderate elevations of direct-reacting bilirubin and aminotransferases, and deep jaundice due to direct-reacting hyperbilirubinemia is an uncommon finding in the course of primary EBV infections in immunocompetent young adults ${ }^{1,7-10}$.

\section{Case report}

A 21-year-old male was admitted because of fever, fatigue, headache, pharyngitis, abdominal pain, loss of appetite, vomiting and dark urine for three days. He did not take any medicine previously to admission, and denied use of illicit drugs, alcohol abuse or tobacco smoking. A vaccinated cat is his pet, and his girl-friend had a recent "flu-like" condition. His physical examination disclosed hepatomegaly, splenomegaly, enlarged tonsils with white exudates and injection, intense jaundice in the skin and in conjunctival mucosa, and bilateral enlargement of supraclavicular and cervical lymph nodes with conspicuous facial and cervical edema resembling a "proconsular" or "bull" neck (Figure 1). The painless lymph nodes had a fibroelastic consistency, with major diameters ranging from 0.5 to $2.0 \mathrm{~cm}$, and were also palpated with similar features on both axillary regions. Abdominal ultrasound images confirmed the moderate hepatic and spleen enlargements. Laboratory findings are showed in Table 1, characterizing an acute hepatitis associated with a recent infection by EBV. Worth of note was leukocytosis and lymphocytosis with a high rate $(24 \%)$ of atypical cells; the initial low platelet count, the elevated serum levels of aminotransferases as well as of the canalicular hepatic enzymes, and the very high (near $13 \mathrm{mg} / \mathrm{dl}$ ) direct-reacting hyperbilirubinemia. The diagnosis was acute hepatitis associated with infectious mononucleosis due to EBV. He was successfully managed with clinical and nutritional support, and symptomatic medicines. After clinical improvement, and tendency to normalization of laboratory data, the patient was discharged home on Day 15, and was further referred to specialized outpatient surveillance. On Day 34,

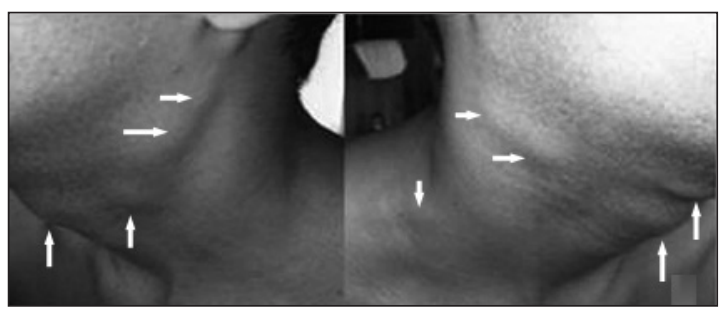

Figure 1. Bilateral enlarged cervical lymph nodes in addition to prominent facial and cervical swelling mimicking a "proconsular neck" or "bull neck" (A and B), and intense conjunctival jaundice in detail (C) on Day 8.

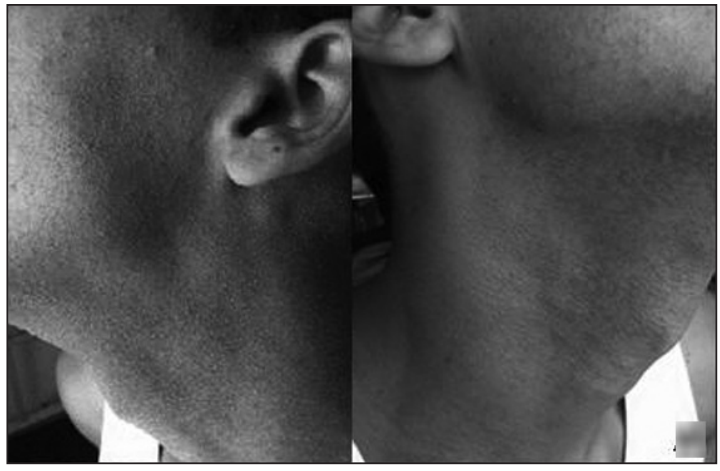

Figure 2. Face and cervical region with normal aspect ( $A$ and B), and absence of ocular jaundice (C) on Day 34. 
Acute hepatitis due to infectious mononucleosis - V. Modesto dos Santos et al

Table 1. Laboratory data of a young male with infectious mononucleosis and acute hepatitis

\begin{tabular}{|c|c|c|c|c|}
\hline Parameter / Day of disease & Day 4 & Day 8 & Day13 & Day 34 \\
\hline Erytrocytes (4.5-6.1 x 1012/L) & 4.91 & 4.09 & 4.01 & 4.25 \\
\hline Hemoglobin (13-18 g/L) & 14.1 & 12.7 & 12.3 & 12.3 \\
\hline Hematocrit (42-52\%) & 42.6 & 36.4 & 35.8 & 37.2 \\
\hline Leukocytes (4.0-10.0 x 109/L) & 8.18 & 19.83 & 18.43 & 4.45 \\
\hline Lymphocytes (1.0-5.0 x 109/L) & 1.30 & 11.69 & 9.21 & 1.42 \\
\hline Atypical lymphocytes (0-2\%) & 24 & 11 & 20 & 0 \\
\hline Platelets (140-450 x 109/L) & 120 & 143 & 153 & 246 \\
\hline Glucose (70-99 mg/dL) & 97 & 105 & ND & ND \\
\hline Urea (16.6-48.5 mg/dL) & 20.7 & 21.7 & 21.8 & 19.0 \\
\hline Creatinine $(0.7-1.2 \mathrm{mg} / \mathrm{dL})$ & 1.1 & 0.8 & 0.9 & 0.9 \\
\hline Sodium (136-145 mmol/L) & 132 & 132 & 134 & 139 \\
\hline Potassium (3.5-5.1 mmol/L) & 4.0 & 4.1 & 4.3 & 3.9 \\
\hline Total bilirubin (1.12-1.32 mmol/L) & 4.0 & 14.5 & 3.9 & 1.1 \\
\hline Direct bilirubin (1.12-1.32 mmol/L) & 3.3 & 12.9 & 3.0 & 0.7 \\
\hline Alkaline phosphatases (40-130 U/dL) & 219 & ND & 260 & 102 \\
\hline Aspartate aminotransferase ( $\leq 40 \mathrm{U} / \mathrm{L})$ & 335 & 697 & 87.0 & 22.4 \\
\hline Alanine aminotransferase ( $\leq 41 \mathrm{U} / \mathrm{L})$ & 297 & 619 & 197.8 & 22.8 \\
\hline Gamma glutamyltransferase (8-61 U/dL) & 374 & ND & 413 & 84 \\
\hline Albumin (3.5-5.2 g/dL) & 3.94 & ND & 3.64 & ND \\
\hline Globulin $(2.9-3.1 \mathrm{~g} / \mathrm{dL})$ & 2.0 & ND & 3.0 & ND \\
\hline Prothrombin activity (70-100\%) & 59 & 81 & 78 & ND \\
\hline INR & 1.37 & 1.13 & 1.15 & ND \\
\hline \multicolumn{5}{|l|}{ Day 6} \\
\hline Anti-HAV IgG: Negative & \multicolumn{2}{|l|}{ HBsAg: Negative } & \multicolumn{2}{|c|}{ Anti-HBc IgG: Negative } \\
\hline Anti-HAV IgM: Negative & \multicolumn{2}{|c|}{ Anti-HBc lgG: Negative } & \multicolumn{2}{|c|}{ Anti-HCV: Negative } \\
\hline Cytomegalovirus IgG: Negative & \multicolumn{2}{|c|}{ Toxoplasmosis: IgG: Negative } & \multicolumn{2}{|c|}{ Anti-HIV-1: Negative } \\
\hline Cytomegalovirus IgM: Negative & \multicolumn{2}{|c|}{ Toxoplasmosis: IgM: Negative } & \multicolumn{2}{|c|}{ Anti-HIV-2: Negative } \\
\hline Epstein-Barr virus: Positive & \multicolumn{2}{|l|}{$\operatorname{lgG}: \mathbf{2 5} \mathrm{U} / \mathrm{mL}$} & \multicolumn{2}{|c|}{$\lg M: 70 \mathrm{U} / \mathrm{mL}$} \\
\hline \multicolumn{5}{|l|}{ Day 34} \\
\hline Epstein-Barr virus: Positive & \multicolumn{2}{|l|}{ IgG: $156 \mathrm{U} / \mathrm{mL}$} & \multicolumn{2}{|c|}{$\lg M: 29 \mathrm{U} / \mathrm{mL}$} \\
\hline
\end{tabular}

HAV: hepatitis A virus; HB: hepatitis B virus; HCV: hepatitis C virus; ND: not done. Abnormal findings are shown in bold.

his physical examination was unremarkable, with absence of jaundice and lymph node enlargement (Figure 2) or visceromegaly. On the same occasion, almost all control laboratory tests were within the normal ranges, except for low indices of red cells and elevated GGT. The serology tests showed an increased level of EBV IgG, while the IgM level had lowered. Actually, the patient is asymptomatic, performing his normal daily activities.

\section{Discussion}

Adolescents and adults usually develop the classical features of IM, with an incubation period from 30 to 50 days $^{10}$, followed by a symptomatic phase of variable duration. Fever, asthenia, headache, myalgias, pharyngitis and lymph node enlargement are the most common signs and symptoms ${ }^{10}$, and our patient presented most of 
them. There was an absolute lymphocytosis, as observed in $70 \%$ of cases with a peak between the second and third weeks. He had a large number (11 to $24 \%$ ) of atypical lymphocytes, which constitutes a major characteristic of IM, although it is not pathognomonic. His serum levels of ALT and AST were moderately elevated, as described in 80 to $90 \%$ of acute infections ${ }^{10}$; and alkaline phosphatases were also elevated, as found in $60 \%$ of the patients with $\mathrm{IM}^{4}$. Discrete elevations of bilirubin occur in about $45 \%$ of patients ${ }^{4}$, but clinical jaundice is observed in only $5 \%$ of cases ${ }^{10}$, in contrast with the very high level of direct-reacting bilirubin observed in the case here reported. Notably, intense cholestasis may affect elderly patients, and can mimic biliary obstruction ${ }^{4}$. Differential diagnoses of IM include other infections (e.g. cytomegalovirus, toxoplasmosis, HIV, rubella, viral hepatitis, leptospirosis, and scratch-cat disease), lymphoma, and leukemia. Interestingly, household contact with cat might raise the hypotheses of toxoplasmosis and scratch-cat disease. However, diagnosis of IM in the patient described herein was based on typical clinical and hematological data, and was confirmed by significant EBV-specific IgM and IgG antibodies ${ }^{10}$. Although acyclovir can inhibit the EBV replication and may reduce viral excretion, it has no significant effects on the clinical manifestations ${ }^{4}$. Uncomplicated cases of IM are usually managed by symptomatic and nutritional support ${ }^{10}$. Mechanisms of liver injuries related to EBV infections are not entirely clear, and include: products of immune responses to viral antigens (interferon $\gamma, \mathrm{TNF} \alpha$, Fas ligand), infected CD8+ T cells, and infiltrating cytotoxic T lymphocytes ${ }^{10}$, in addition to immunodeficiency syndromes, complement deficiency, X-linked lymphoproliferative disease, or treatment ${ }^{8}$. Because the prevalence of IM is very high worldwide ${ }^{7,8,10}$, there is a concern about possible under diagnosis, misdiagnosis, or underreporting of EBV-induced liver changes ${ }^{8}$. Although EBV-related acute hepatitis with jaundice has been scarcely reported, this condition may be under diagnosed in young patients ${ }^{9}$, because clinical and laboratory features (except for serology data) may be identical to that associated with the classic hepatotropic viruses ${ }^{4}$. Kang et al described two cases of acute hepatitis by EBV in Korean adults (aged 20 and 24 years) and, worth of note, one of them presented concomitant infection by hepatitis A virus ${ }^{10}$. Clinical findings and laboratory data were similar in both cases; however, the patient with hepatitis A virus coinfection showed two times higher levels of total ( 4.0 versus $2.1 \mathrm{mg} / \mathrm{dl}$ ) and of direct-reacting (2.4 versus $1.2 \mathrm{mg} / \mathrm{dl}$ ) bilirubin, and lower levels of GGT ( 69 versus $235 \mathrm{U} / \mathrm{l}$ ). Interestingly, both patients improved with clinical management in a period of two weeks ${ }^{10}$. Cybulska et al reviewed three cases of EBV-related acute hepatitis in Canadian pediatric patients aged from 5 to 14.4 years. Their clinical course was benign, with abdominal pain, jaundice and ALT levels ranging between 126 and $196 \mathrm{U} / \mathrm{ml}$, which normalized with time ${ }^{11}$. Other authors have emphasized that many discharge diagnosis of viral hepatitis in children have no confirmed etiology, contributing to under detection of other hepatotropic viruses like $\mathrm{EBV}^{11}$. Kofteridis et al reviewed 41 cases of acute hepatitis by EBV in Greek adults with a median age of 18.5 (15-51) years, and described a self-limiting condition, mainly cholestatic ${ }^{12}$. Similar to the laboratory findings in our patient, the levels of AST and ALT started to rise early in the onset of IM, and normalized in about three weeks, as well as the bilirubin and alkaline phosphatases, while the levels of GGT normalized later (after a period of 30 days $)^{12}$. Vine et al reviewed 17 patients with diagnosis of acute hepatitis by EBV in the UK and found an age range of 18-68 years (median of 40 years). Seven patients ( $41 \%$ ) were aged $\leq 30$ years, similar to the present report. Brief hospitalization was necessary for three of the 17 patients, and the course of acute hepatitis was anicteric in two cases. They concluded that EBV hepatitis is an uncommon self-limiting entity, mainly detected among people aged $\geq 60$ years ${ }^{9}$. The purpose of this case study is to highlight the intense jaundice (bilirubin $>14 \mathrm{mg} / \mathrm{dl}$ ) due to an acute hepatitis caused by EBV, which occurred in a young adult with classical IM. We also emphasize that EBV infections can origin acute hepatitis with cholestasis, and can contribute to diagnosis pitfalls in primary care settings. Case studies may enhance the suspicion index about acute hepatitis by EBV, possibly under recognized in young patients.

\section{References}

1. Prieto de Paula JM, Mayor Toranzo E, Franco Hidalgo S. Report of eight cases of acute hepatitis due to EpsteinBarr virus. Gastroenterol Hepatol 2012; 35: 103-5. 
2. Ferrés M, Prado P, Ovalle J, Fuentes R, Villarroel L, Ferreccio C, et al. [Seroprevalence of Epstein Barr virus infection in a healthy population of Santiago de Chile]. Rev Med Chile 1995; 123: 1447-52.

3. Luchsinger V, Luzoro A, Martínez MJ. [High seroprevalence of cytomegalovirus, herpes simplex type 1 virus and Epstein Barr virus infection among human immunodeficiency virus-infected adults]. Rev Med Chile 2010; 138: 809-14.

4. Gallegos-Orozco JF, Rakela-Brödner J. [Hepatitis viruses: not always what it seems to be]. Rev Med Chile 2010; 138: 1302-11.

5. Okano M, Gross TG. Acute or Chronic Life-Threatening Diseases Associated With Epstein-Barr Virus Infection. Am J Med Sci. 2011 Nov 17. [Epub ahead of print].

6. Albornoz V, Wainstein E, Andrade A, Reyes H. [Hepatitis by infectious mononucleosis]. Rev Med Chile 1991; 119: 1109-14.

7. Barreales M, Pérez-Carreras M, Meizoso T, Garrido M, Masedo A, Colina F, et al. Infección por el virus de
Epstein-Barr y hepatitis aguda colestásica. An Med Interna (Madrid) 2006; 23: 483-6.

8. Ulug M, Çelen MK, Ayaz C, Geyik MF, Hosoglu S. Acute hepatitis: a rare complication of Epstein-Barr (EBV) infection. J Infect Dev Ctries 2010; 4: 668-73.

9. Vine LJ, Shepherd K, Hunter JG, Madden R, Thornton C, Ellis V, et al. Characteristics of Epstein-Barr virus hepatitis among patients with jaundice or acute hepatitis. Aliment Pharmacol Ther. 2012 May 3. doi: 10.1111/j.1365-2036.2012.05122.x.

10. Kang MJ, Kim TH, Shim KN, Jung SA, Cho MS, Yoo $\mathrm{K}$, et al. Infectious mononucleosis hepatitis in young adults: two case reports. Korean J Intern Med. 2009; 24: 381-7.

11. Cybulska P, Ni A, Jiménez-Rivera C. Viral hepatitis: retrospective review in a Canadian pediatric hospital. ISRN Pediatrics 2011; 2011: 182964. Epub 2010 Dec 29.

12. Kofteridis DP, Koulentaki M, Valachis A, Christofaki M, Mazokopakis E, Papazoglou G, et al. Epstein Barr virus hepatitis. Eur J Intern Med 2011; 22: 73-6. 